\title{
Third Place Design Strategy for Commuter in Sub-urban (Case Study: Outdoor Public Space in Tangerang City, Indonesia)
}

\author{
Mustika K Wardhani ${ }^{1}$, Tomohiko Yoshida², Alpraditia Malik² \\ ${ }^{1}$ Research Organization of OIC Ritsumeikan University, Osaka, Japan \\ ${ }^{2}$ Graduate School of Policy Science Ritsumeikan University, Osaka, Japan \\ Corresponding e-mail: mk1698@fc.ritsumei.ac.jp \\ Article info: \\ Received: 07-09-2020, Revised: 19-10-2020, Accepted: 24-10-2020
}

\begin{abstract}
In recent years, Urban population density spreads towards suburbs of the metropolitan city as the impact of urbanization. In Indonesia, Commuting activity does not only occur in the centre of metropolitan city Jakarta but spreads outside to the suburbs such as in Tangerang City. Commuting activities often cause stress, and some outdoor public spaces are expected to be healing space for recreation needs amidst a busy life. The lack of integration of urban design that supports commuting activities along with leisure activities is a problem that will be raised. This paper objectivity is to see the configuration of a potential location as the third space in Tangerang City infrastructure around bus stops and train station. The method is chosen to be applied a qualitative method with a rationalistic approach. Study findings postulated three paradigms in Tactical Urbanism design strategy, which are: (1) Functionally, Tactical Urbanism can form a multipurpose proximity network that functions simultaneously between mobility and relaxation activities; (2) Socially, tactical urbanism design strategy can eliminate social segregation where there are no gaps to spend leisure time around Tangerang station for commuter, community, also tourist; (3) Visually, Tactical Urbanism can encourage people to come and sit for a while and become an icon of Tangerang City with the design of public open spaces integrated with infrastructure for transportation. Based on the above findings, a framework is conceptualized as an attempt to strengthen the tactical urbanism design strategy in the suburbs area.
\end{abstract}

Keywords: Commuting \& Leisure Behaviour, Third Place, Tactical Urbanism, Outdoor Public Space in Suburbs

\section{Introduction}

The increasing number of residents in Metropolitan City is not only calculated from the birth rate but also the presence of migrants who live in the sub-urban \& work or study in the city centre. The Population in Jakarta, as many as $10.467,63$ people in $2019^{1}$, is the number of 'nighttime' residents. Jakarta's population is different at night compared to the daytime influenced by commuters who are entering Jakarta. Based on Jabodetabek Transportation Management Agency (BPTJ) data in 2018, the total number of trips taken in the Jabodetabek region attain to 49.5 million trips per day. Of the many total trips that have been taken, 23,4 million people move within Jakarta, while the other 20,02 million are Bodetabek residents whose mobility from outside of Jakarta.2

Tangerang City is a city bordering the Jakarta Metropolitan Area (JMA), which is impacted by high commuter mobility activities. From a social aspect, Tangerang has segregation consisting of upper, middle, and lower classes, which affects commuter preferences in mobility disparities. Mobility disparity in commuter activities can be categorized into various modes of transportation consisting of private, public, and mixed transportation modes, which will form a commuting behaviour pattern. Commuter behaviour patterns will form a network of supporting

\footnotetext{
${ }^{1}$ https://jakarta.bps.go.id/, 2020

2 http://bptj.dephub.go.id/rencana-induk-transportasi-jabodetabek-ritj, 2020
} 
activities for commuters such as Third place for recreation, relaxation, and spending leisure time in the middle of a busy life. According to (Oldenburg \& Brissett, 1982), The definition of the third place is a space for leisure time, in which the first place is the house, and the second is the office, school, or campus. Also (Hadi and Ellisa, 2019) said states that the third place is the potential social space for inclusive social activities. Besides, the third-place creates and maintains the relationship and various kinds of human interactions and efforts to create a sense of place and public common space for visitors (Lawson, 2004). From the above understanding, it can be concluded that the third place is a space for community and social interactions that can support democracy and local spirits.

There are various kinds of outdoor leisure behaviour such as activity in freely disposable time like cycling on roads, outdoor exercise, sport on the ground, relaxation, recreation, commuter waiting for inter-mode changes, meet \& interact with friends or relatives, reduce stress, \& other purposes that make use of public open space. Outdoor public open space in this research means a city or regional parks, district parks, pocket parks, green spaces conservation, riverfront \& canal recreation, pedestrian paths, private roads, lake/pond, bamboo \& wood Park (conceptual parks managed by private but available for public access), town square, and plaza. These activities require a tactical design strategy concept so that it can be optimal and integrated. In urban scale understanding, tactical urbanism, according to Lydon (2015), defined as a short-term effort to provide long-term effects. In other words related to the concept for building the environment and the activation of implementing, tactical urbanism associated with low-cost and scalable interventions. Tactical urbanism can be used as an intervention effort, which can bridge the gap between bottom-up and top-down policies by designing a strategic arrangement to provide benefits for both parties (Yassin, 2019).

Regarding Smart City Concept in Tangerang City is divided into three stages, starting from Smart City 1.0, Smart City 2.0 and that has been implemented in 2018 is Smart City 3.0. According to Adi Zulkifli from the Ministry of Communication and Information Technology (Tangerang City) said that Smart City 1.0 is an integration of every service application that has been built. Then Smart City 2.0 is focused on improving public services, and Smart City 3.0 utilizes geospatial technology so that public services can be right on target (Parameswari, 2020). The novelty of the research is to be able to figure out an urban design concept that can be applied in the suburbs of JMA departing from issues related to commuter and leisure behaviour. It is hoped that from this study, it can be a reference for Architects to solve problems related to the optimization of public space integration with other infrastructures such as the train station and bus stop. The result of research also can be considered by the Jabodetabek Transportation Management Agency (BPTJ) and stakeholders related to public space in suburbs who can collaborate in urban infrastructure design as the aspect that is integrated with other systems, in this case, the transportation \& recreation.

\section{Methods}

This research uses an analysis of the tactical urbanism design strategy and its relationship with urban design dimension in outdoor public space. The study used a descriptive qualitative method by describing a field phenomenon that occurred to analyze existing potentials. The descriptive study aims to describe a phenomenon with strict, careful, and standard observation, which relies on objectivity (Furchan, 2004). Moreover, this research will use the Rationalistic approach regarding (Hjørland, 2005), rationalism seeks more "top-down" analysis in information processing, that is, approaching a particular set of data from some predetermined category. 


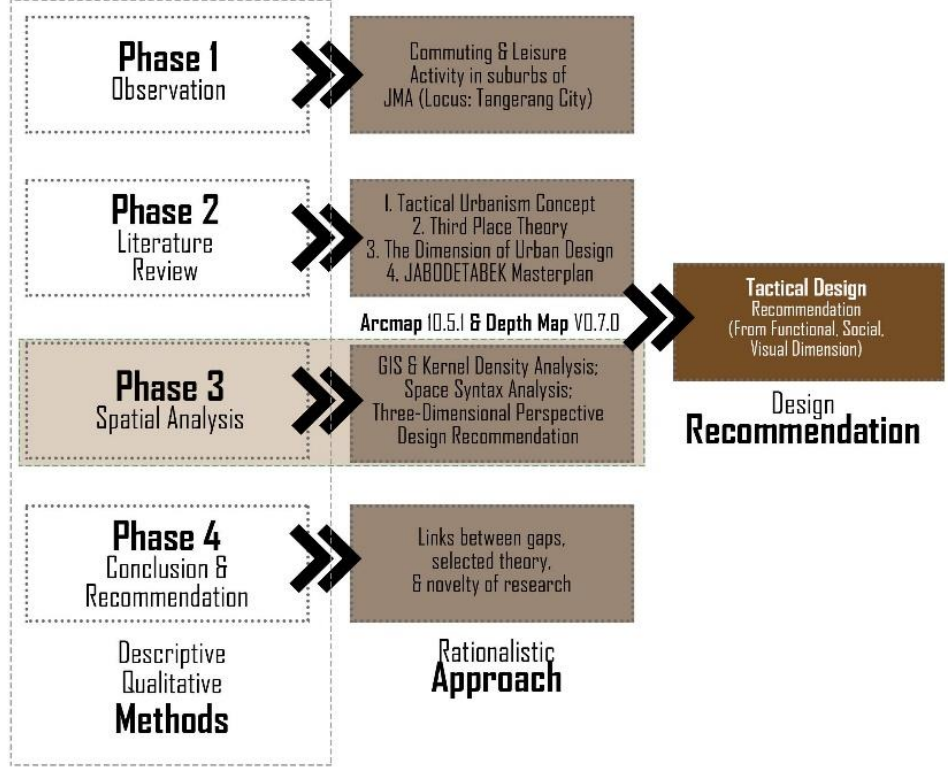

Figure 2.1. Research staging scheme (Author, 2020)

A rationalistic approach in analyzing an existing problem is visualized by the geographic information system using Arcmap 10.5.1 and space syntax analysis using Depth map V0.7.0 software. Space syntax here is a consideration tool of urban network analysis or the map graph that can provide a computational description of the selected research locus. (Valipour et al., 2019).

\section{Discussion}

According to United Nations ESCAP (2017), In 2000, trips taken using public transportation in Jabodetabek were $58 \%$ and decreased significantly in 2010 by $28 \%$. Also (Edwards \& Tsouros, 2006) said what is meant by the built environment includes the pattern of land use and various type of buildings, spaces and elements constructed and modified by humans. This includes homes, schools, campus, workplaces, parks, recreation point, green area, business-oriented space development and transportation systems. Urban design is an aspect of planning that focuses on creating the desired environment for living, working, and recreation. From the health aspect, some stimulus is needed to intervene in public open space to become integrated with recreation spaces for commuters. Based on the Introduction about tactical urbanism design strategy for commuting activity, some of the variables can be solved by a design strategy such as (1) Disconnected' area needs to extend the sense of commuter mobility life in Suburbs; (2) Transitional spaces as third place require a stimulus to be integrated with various modes of transportation, (3) Encourage commuters to use public transportation by increasing the sense of walkability with the existence of public space to reduce congestion due to private vehicle mobility. The strategies for solving the above problems can be explained in the following discussion:

\subsection{Population Distribution in JABODETABEK \& Public Transport User in JMA}

In the case of Jakarta, Bodetabek has become the target as a place for living. Meanwhile, the area of Jakarta has only $661,5 \mathrm{~km}^{2}$, and if it is calculated correctly, the population density is relatively high, which is 15.052 people/ $\mathrm{km}^{2}$. While the "urban sprawl" is happening, Jakarta is no longer a metropolitan city anymore, but a Megapolitan city. Therefore, Jakarta needs to build an adequate transportation infrastructure to provide the transportation needs of the citizen, because it is not only Jakarta anymore, but also the citizen of Bodetabek (Purnomo et 
al., 2017). The Population distribution of the outskirt of Jakarta Metropolitan Area (JMA) in 2019 can be seen as follows (See figure 3.1):

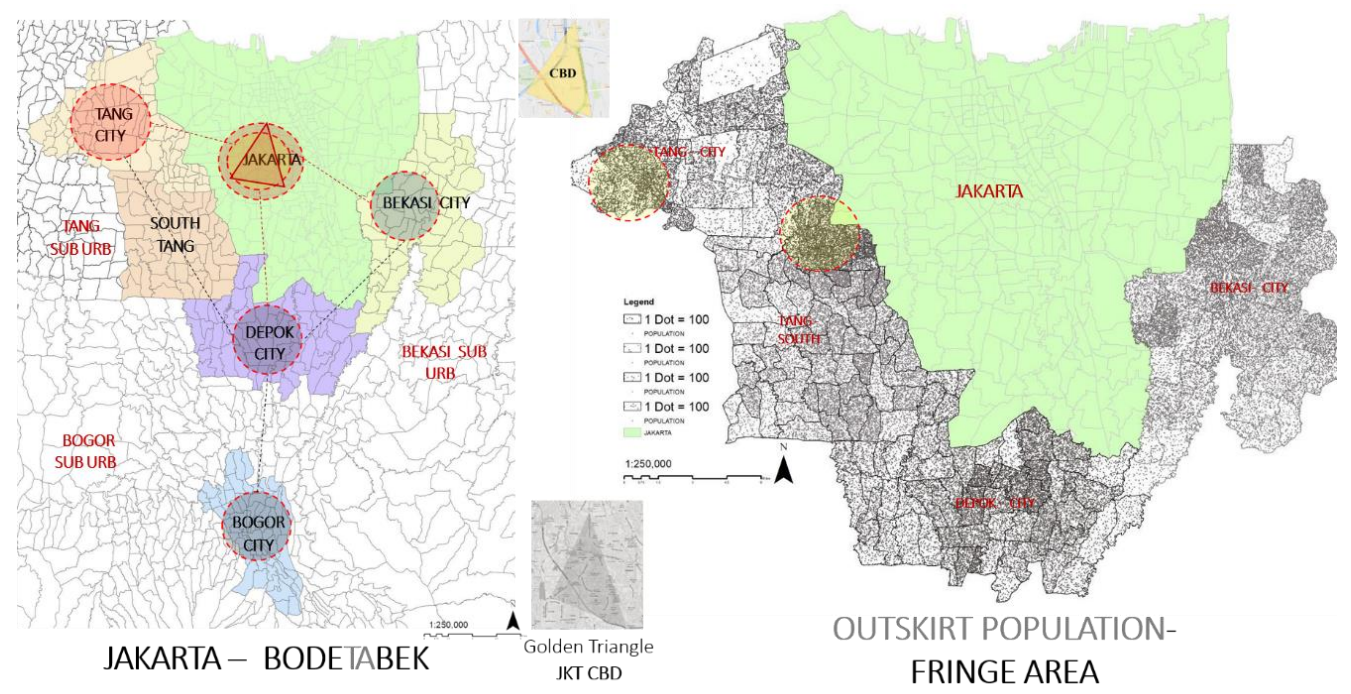

Figure 3.1. The population density in Jakarta Suburbs Area by BPS data 2019 (Author, 2020)

Tangerang City becomes the locus of the research to be observed more tactically through the issues that occur and related to government programs that have been planned. Apart from being seen from the distribution of the population, social segregation, and economic status affect commuters in choosing the mode of transportation that is used daily. According to (JICA 2012 ) in its report found that the average income of motorcyclists (34\%) dominates the portion of daily commuter trips in The Jakarta Metropolitan Area (See Table 3.1):

Table 3.1. Table Modal Share by Income Level by JMA's Commuter (Japtrapis, JICA-Mot, 2012)

\begin{tabular}{ccccc}
\hline Mode & $\begin{array}{c}\text { Economic } \\
\text { Status }\end{array}$ & Daily Trips & Share & $\begin{array}{c}\text { Mode } \\
\text { Share }\end{array}$ \\
\hline Lower-income & 8.314 .748 & $16 \%$ & \\
Medium income & 17.801 .390 & $34 \%$ & \\
High income & 2.007 .651 & $4 \%$ & \\
\hline Lower-income & 1.211 .348 & $2 \%$ & $20 \%$ \\
Medium income & 7.233 .139 & $14 \%$ & \\
High income & 2.056 .607 & $4 \%$ & \\
\hline Lower-income & 5.323 .158 & $10 \%$ & $\mathbf{2 7} \%$ \\
Medium income & 8.466 .125 & $16 \%$ & \\
High income & 637.535 & $1 \%$ & \\
& 53.051 .701 & $100 \%$ & $100 \%$ \\
\hline
\end{tabular}

From the table 3.1, we can see the phenomenon that private motorcycle person trips still dominate commuting behaviour in Jakarta. The effort that should apply in this case is what concepts can be a stimulus to provide solutions to encourage commuters to choose public transportation dan to reduce trips using private vehicles with the availability of transitional spaces. This research will focus on the potential availability of outdoor public space to support commuting activities from suburbs to the JMA and vice versa. So the proximity of outdoor public space and transport interchange will be the next analysis in determining the potential location. 


\subsection{Population Density by Village in 2019 and The Availability of Various Transportation Mode Stop Point in Tangerang City}

Population Density in Tangerang City by Village in 2019, based on data from the Central Statistics Agency (BPS) ${ }^{3}$ and visualized with mapping as follows (see Figure 3.2):

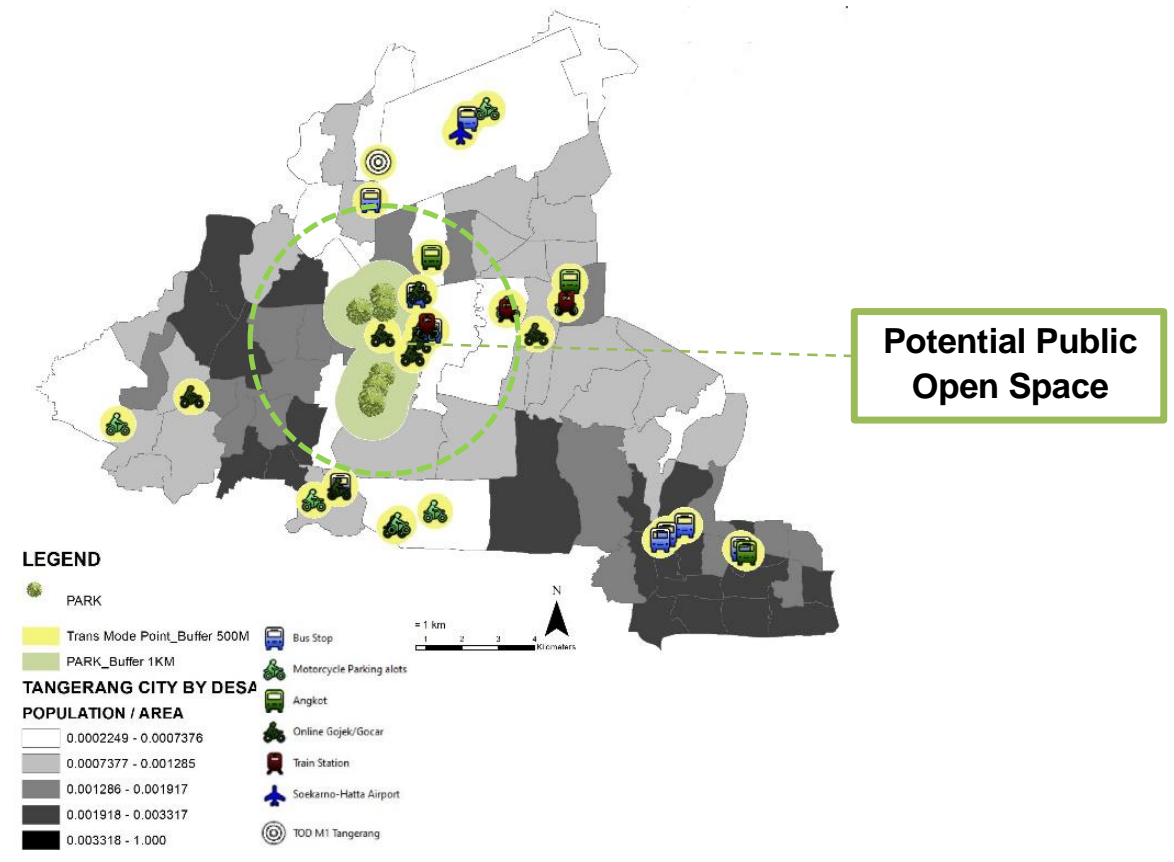

Figure 3.2. Tangerang's Population density by the village from BPS data in 2019 \& The availability of mass transit stops in Tangerang city (Author, 2020)

According to (Haas \& Mehaffy, 2019) Cities, much of which have been studied, are primarily complex adaptive systems. Public open space systems offer users a useful key point for understanding and managing challenges that will arise in cities and particularly in the context of urbanization in the future. Also, (Oughton et al., 2018) said the national infrastructure system, which includes a discussion of energy, transportation, digital, waste, and water is recognized as a complex and interdependent system. The complex challenge here means how the residents obtain adequate outdoor open space facilities also as part of their commuting activity. According to several Publications before, They Argue that cover longer distances and times for commuters are systematically associated with lower welfare (Frey and Stutzer, 2008; Novaco \& Gonzalez, 2009). Also, Long commuting causes stress for urban workers (Schaeffer et al., 1988; Hennesy and Wiesenthal, 1999; Wener et al., 2003; Gottholmseder et al., 2009; Novaco et al., 1990). Apart from that understanding, the correlation between commuting activity and health shows the tendency of a negative relationship (Walsleben et al., 1999; Jansen et al., 2003; Hämming et al., 2009; Hansson et al., 2011; Roberts et al.,2011). From these references, the existence of 'healing space' is expected to meet the needs of suburban Commuters.

From the results of GIS analysis, It can be seen that the highest population density in Tangerang City is approaching the outskirts of West Jakarta and South Tangerang. This population density is the reason to focus on Tangerang City, which has the highest population and the potential for adjacent public space. By analyzing the 500-meter buffer zone from the green open space point distribution in Tangerang City Centre, it can be easily found the

\footnotetext{
${ }^{3}$ https://tangerangkota.bps.go.id/, 2020
} 
Motorcycle-taxi called Gojek/Grab stop point, Bus stop, and Tangerang train station. These three transit points have the potential to be connected. By connecting various modes of transport stop point with potentially outdoor public space, it can be an effort to reduce stress for workers by designing a space that accommodates leisure activities.

\subsection{The Proximity of Public Open Space \& Transit Distribution stops point in Tangerang City based on Kernel Density Analysis}

With the program targeted by the Government to be achieved in the RITJ, by the end of 2029, people mobility using urban mass public transportation is expected to reach $60 \% .{ }^{4}$ In Additional (RITJ 2018) also states that the planning of a mass transportation system that is carried out takes the accessibility of urban public transport services which is expected to reach $80 \%$ of the road's total length. Each village should have a local transportation network or what is called a feeder integrated with the leading network through one urban transportation node. In line with the previous argument, the limited urban space to accommodate the competitive flow of various types of movement: motorized and non-motorized, individual and collective, sooner or later, they all tend to share in common ground aimed at finding a balance between motorized and non-motorized traffic on urban roads, and more specifically between traffic and the "immovable" use of public space associated with mobility (Bertolini, 2020). This becomes the basis for analyzing the potential proximity of open space to transit stop points in suburban as a solution to support commuting activities. To see the space that potentially can be integrated, it can use Kernel Density Analysis (KDA) see (Figure 3.3.):

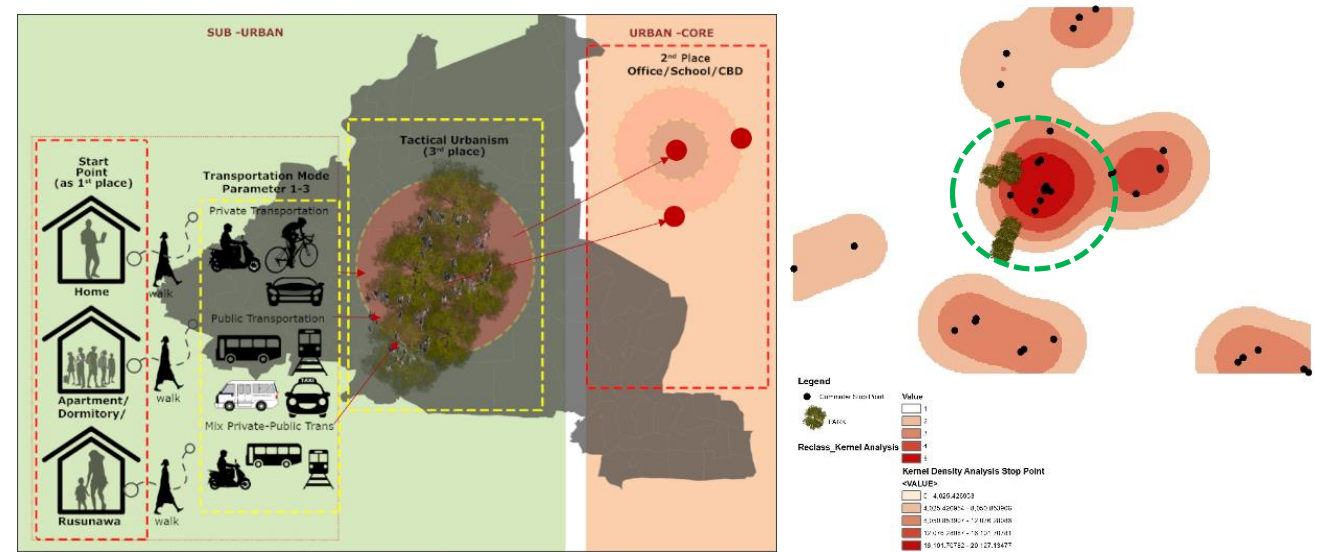

Figure 3.3. The proximity between Transportation stop and Potential Public Open Space (outdoor) using Kernel Density Analysis by Arcmap 10.5.1 (Author, 2020)

Kernel Density Analysis is an effective method of spatial element analysis in ArcGIS. It is mainly used to calculate the concentration of specific elements within the scope of the neighbourhood. This method is applied at specific points as the centre and makes the distribution of its properties in the specified thresholds range. It means in a circle with the radius $r$, the density is most prominent in the centre and gradually weakened outwards (Modica et al., 2012). From the results of KDA, it can be seen that the proximity of the outdoor public space is in Tangerang City centre (near the Tangerang train station area).

From KDA, the authors can determine the selected sites that tend to be tactically intervened by looking at tangible and tangible aspects. The selected site is on the banks of Cisadane river, behind Al-Ittihad Great Mosque Tangerang and is included in the old town area of Tangerang which has a history of Colonialism era. Another potential is the existence of Tangerang Night

${ }^{4}$ Presidential Decree (Perpres) Number 55 the year 2018 regarding Jabodetabek Transportation Master Plan (RITJ) 
Culinary as a local aspect which becomes its attraction in the availability of culinary tourism around open spaces that will be intervened. The subsequent analysis is to look at the functional, social, and visual dimensions in tactical urbanism design strategy.

\subsection{Tactical Urbanism Design Strategy as Creative Leisure based on Functional, Visual, and Social Dimension}

A successful design strategy is an objective of integrating the public space requirements of commuting and leisure behaviour. As mention on (Carmona, 2019), the public space can be said to be successful if 1 . Can be developed (from both the formal and informal sectors); 2 . Prioritizing diversity (avoid commonalities and concepts tend to suit everyone); 3 . Free (by guaranteeing rights and remaining responsible); 4. Delineate (clearly used for open and public purposes); 5. Captivating (designing inactive uses); 6. Meaningful (integrates essential facilities and features); 7. Social (stimulates social interaction); 8. balanced (between pedestrians, cyclists, and traffic). Also, according to (Carmona et al., 2010), there are six dimensions of urban design as follows: Morphological, Perceptual, Social, Visual, Functional, and Temporal Dimensional. In this case, the observation variable used is selected as many as three leading factor analysis indicators based on existing condition on the field:

- Functional Dimension (Muti-Purposes; Inclusive \& Universal Design)

- Visual Dimension (Iconic; Networking; Green Path for Walkability Concept)

- Social Dimension (Decrease Social Segregation; Metting point)

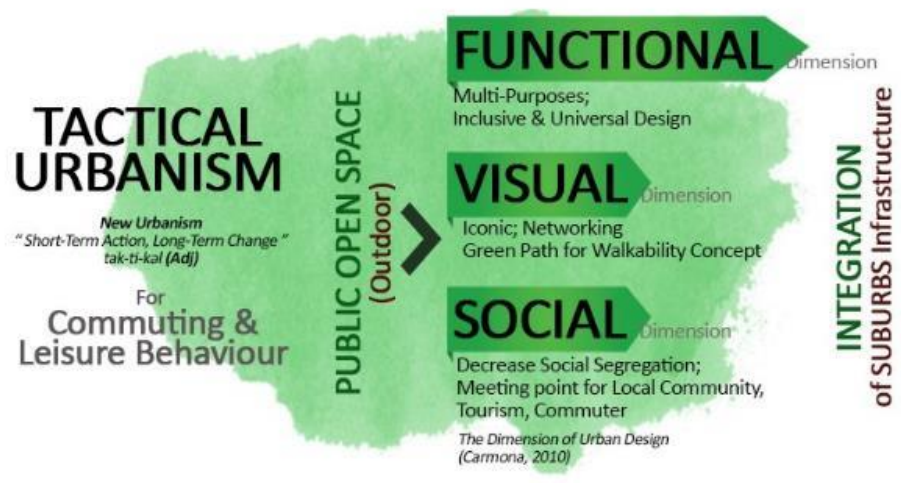

Figure 3.4. A research framework for the proposed approach (Author, 2020)

Outdoor public open space is some part of the urban planning element that describes the city's image as a space for social engagement and visually becomes a city's icon. The visual, social, and functional dimensions of urban space will create a sense of place with a unique and strong character in the selected location (Wardhani, 2018). Additionally, Design investment in landscaping and recreational facilities can be a practical step to increase the opportunities for physical activity in the elderly and generate health benefits. An outdoor physical activity represents a correlative potential that can be an alternative in reducing health care costs (Sato et al., 2019). The sense of public space will be a stimulus to encourage Commuters, Tourists, Elderly, and all communities to visit outdoor space in the transition area. Also, six factors influence the determination of transition area needs, such as physical comfort, public space, visual quality, supporting facilities, and culinary (Utami \& Kusuma, 2016).

Apart from being able to be viewed from the dimension of urban design, the analysis of open space in this study also uses the Space Syntax Analysis to identify integration and human 
visibility of space. The Space Syntax is used to show urban road networks and the movement of lines in grid frames and as a tool for building natural functional units.

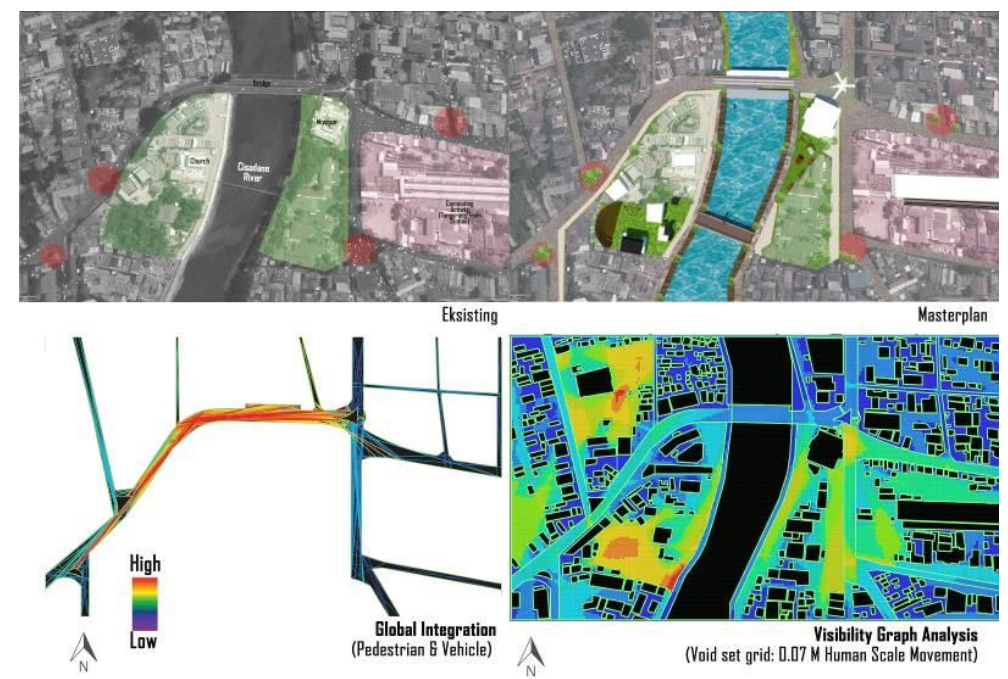

Figure 3.4. Integration \& Visibility Graph based on Space Syntax analysis (Author, 2020)

In the analysis using Depth MapX 7.0, there are two discussions on the integration and visibility graph of the selected site around the Cisadane river Tangerang before interventions. The output of global analysis integration is a line representing the axial integrity value over an infinite radius. It can be used as a tool to represent the image of integration even on a largescale pattern. In this case, global integration consisting of a vehicle and human integration ${ }^{5}$. The lowest integration point is blue, and the highest integration is in the red part, around the highway Merdeka street bridge. The result of integration analysis is how the provide access tactically by shortening the distance from the station to the across area by adding a bridge for pedestrians and bikers.

Visibility Graph Analysis is used as a tool to investigate the properties of the visibility graph derived from the selected spatial environment in particular grid size. The VGA applied here for what people can see to understand spatial layouts. ${ }^{6}$ With a grid set average, human movement (0.7 Meter) indicates that the area near the red dot in void element (here the riverside, bridge, and road), is the point that most visible to the human eye. In the area of red dots, it can be given icons, landmark, bench, or sitting points. The final results of the GIS and space syntax analysis above can be strengthened by design in the Three-Dimensional Perspective (after interventions) as follows (see Figure 3.5):

${ }_{6}^{5} \frac{\mathrm{https}: / / \text { www.spacesyntax.online/term/axial-global-integration/, }}{\underline{\text { https://www.spacesyntax.online/term/visibility-graph-analysis-vga//, } 2020}} 2020$ 


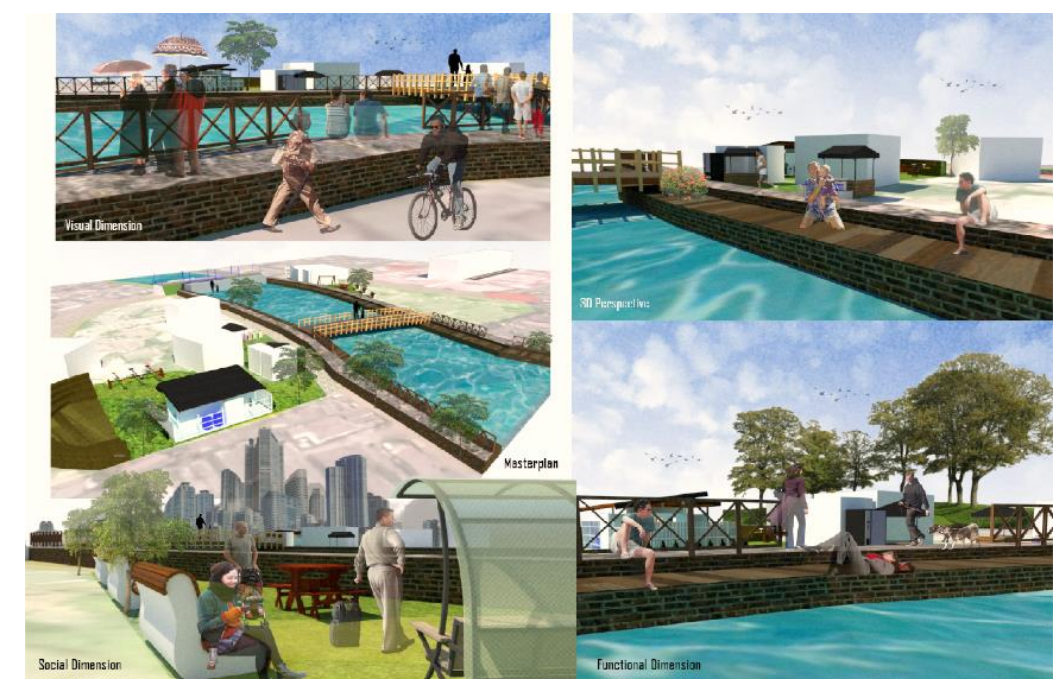

Figure 3.5. Three-Dimensional Perspective of third-place near Cisadane River (Author, 2020)

Urban transportation nodes are expected to have facilities for pedestrians, which include park and ride so that the transfer between modes to public transport becomes efficient. For this reason, the intermodal transfer distance is designed to be maximum of 500 meters. This includes pedestrian and cyclist access to mass transportations no more than 500 meters. ${ }^{7}$ Also, the satisfaction of park quality is related to perceptions that promote other life satisfaction, including better environmental, social connections, the involvement of natural balance, outdoor sports opportunities, and relatively lower scale environmental disturbances (Pfeiffer et al., 2020). Tactical Urbanism at the selected location is applied to a buffer zone 500 meters from Tangerang station and also proximity to other City infrastructures which has cultural significance such as Al-Ittihad Tangerang City Great mosque, Heritage Museum, Government Office, Pasar Lama Tangerang in Old Town Area and also Tangerang Night Culinary in Kisamaun street. Overall, Tactical Urbanism can be an alternative solution in implementing government programs with the suitability of its substance in the urban design dimension and integration analysis.

\section{Conclusion}

Urban design is contributing to a new global movement towards a better human life and the environment. The critical part of the urban design strategy is, "If you design cities for machines and traffic, you get machines and traffic. If you design cities for people and places, you get

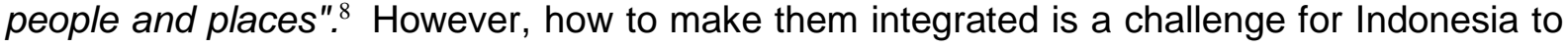
adopt Smart City 3.0, which is based on community co-creation. Therefore here, Tactical Urbanism seeks to be a solution to the problem of urban space needs, especially for commuters' leisure time. Tactical Urbanism is a concept that can serve as a stimulus for urban commuters, local community, and tourism as well, especially their ease of reaching outdoor open space near transit points for multi-purposes activity.

Relaxation activities amidst stress at work and high traffic jams will be healing given by the city as an effort to create a healthy urban space for commuters. The attractive variable in designing outdoor public space can encourage commuters to visit the outdoor area, especially in this Covid-19 pandemic situation. Stress healing is not only from the medical aspect but here, and urban space can also be alternative healing.

\footnotetext{
7 Presidential Decree Number 55 The Year 2018 regarding Jabodetabek Transportation Master Plan (RITJ), 2020

8 https://www.terravivacompetitions.com/tactical-urbanism-now-competition/,2020
} 
Tangerang City, as suburbs of JMA, has the potential for outdoor public space in terms of functional, visual, and social dimensions, focus in the 500 Meter buffer zone area from Tangerang Station. There is at least one node in each city transition in BODETABEK as a response concept in Society 5.0, which is related to Human-centered Society for high-quality of life. Based on the above findings, a recommendation is conceptualized as an attempt to strengthen the tactical urbanism design strategy in the suburbs area. The Tactical Urbanism concept in the third place can make the existing outdoor public space more attractive to become a 'new place' for everybody.

\section{Acknowledgements}

This research is supported by JSPS KAKENHI Grant Number $19 \mathrm{H} 02325$

\section{References}

Bertolini, L. (2020). From "streets for traffic" to "streets for people": can street experiments transform urban mobility? Transport Reviews, 0(0), 1-20. https://doi.org/10.1080/01441647.2020.1761907

Carmona, Matthew., Tiesdell, Steve., Heat, Tim., Oc, Tanner. (2010). Public Places - Urban Spaces. The Dimensions of Urban Design. Second Edition. Elsevier. Italy. ISBN-13: 9781-85617-827-3

Carmona, M. (2019). Principles for public space design, planning to do better. Urban Design International, 24(1), 47-59. https://doi.org/10.1057/s41289-018-0070-3

Central Bureau of Statistics - Jakarta Province Total Population 2019 (1 September 2020) Citing Internet source https://jakarta.bps.go.id/

Central Bureau of Statistics - Tangerang City Population Density (3 September 2020). Citing Internet source https://tangerangkota.bps.go.id/

Edwards, Peggy and Tsouros, Agis. (2006). The Solid Facts WHO "Promoting physical activity and active living in the urban environment" The Role of Local Governments. ISBN: 92890-2181-0. https://www.euro.who.int

Frey, B.S., and A. Stutzer. (2008). Stress that Doesn't Pay: The Commuting Paradox, Scandinavian Journal of Economics 110, 339-366

Furchan, A. (2004). Pengantar Penelitian dalam Pendidikan. Yogyakarta: Pustaka Pelajar.

Haas, T., \& Mehaffy, M. W. (2019). Introduction: the future of public space. Urban Design International, 24(1), 1-3. https://doi.org/10.1057/s41289-018-0062-3

Hjørland, B. (2005). Empiricism, rationalism, and positivism in the library and information science. Journal of Documentation, 61(1 SPEC. ISS.), 130-155. https://doi.org/10.1108/00220410510578050

Jabodetabek Transportation Management Agency-BPTJ (3 September 2020). Citing Internet source http://bptj.dephub.go.id/rencana-induk-transportasi-jabodetabek-ritj

JICA. (2012). Project for the Study on Jabodetabek Public Transportation Policy Implementation Strategy (JAPTraPis) - Final Report.

Lawson, K. (2004). Libraries in the USA as traditional and virtual third places. New Library World, 105(1198), 125-130. https://doi.org/10.1108/03074800410526758

London's Global University (UCL) - Space Syntax Laboratory (1 September 2020). Citing Internet source https://www.spacesyntax.online/term/visibility-graph-analysis-vga/

Lydon, Mike., and Garcia, Anthony. (2015). Tactical Urbanism: Short-term Action for Longterm Change. Washington, DC: Island Press. 256 pages.

Modica, G., Vizzari, M., Pollino, M., Fichera, C. R., Zoccali, P., \& Di Fazio, S. (2012). Spatiotemporal analysis of the urban-rural gradient structure: An application in a Mediterranean mountainous landscape (Serra San Bruno, Italy). Earth System Dynamics, 3(2), 263-279. https://doi.org/10.5194/esd-3-263-2012 
Oldenburg, R., \& Brissett, D. (1982). The third place. Qualitative Sociology, 5(4), 265-284. https://doi.org/10.1007/BF00986754

Oughton, E. J., Usher, W., Tyler, P., \& Hall, J. W. (2018). Infrastructure as a Complex Adaptive System. Complexity, 2018(November). https://doi.org/10.1155/2018/3427826

Parameswari, R. (2020). The Effect Quality Tangerang Live To Public Satisfaction In Taman Royal 2. Parapolitika: Journal of Politics and Democracy Studies, 1(1). Retrieved from https://parapolitika.upnvi.ac.id/index.php/pp/article/view/7.

Pfeiffer, D., Ehlenz, M. M., Andrade, R., Cloutier, S., \& Larson, K. L. (2020). Do Neighborhood Walkability, Transit, and Parks Relate to Residents' Life Satisfaction?: Insights From Phoenix. Journal of the American Planning Association, 86(2), 171-187. https://doi.org/10.1080/01944363.2020.1715824

Presidential Decree of Indonesia (Perpres) Number 55 the Year 2018 regarding Jabodetabek Transportation Master Plan (RITJ)

Purnomo, R. Y., Syahreza, A. E., \& Gani, R. Z. (2017). Sudirman Transit Centre as Transport Infrastructure Innovation for Integrated Intermodes in Jakarta. Indonesian Scholars International Convention (ISIC) and $16^{\text {th }}$ Conference - Temu IImiah Mahasiswa International Indonesia (TMII) in October 2016. Full Paper.

Hadi and Ellisa, E. (2019). Rethinking third place in the digital era. Bali, November 2019. International Conference on Informatics, Technology and Engineering (InCITE 2019). Universitas Surabaya (UBAYA).

Sato, M., Inoue, Y., Du, J., \& Funk, D. C. (2019). Access to parks and recreational facilities, physical activity, and health care costs for older adults: Evidence from U.S. counties. Journal of Leisure Research, 50(3), 220-238. https://doi.org/10.1080/00222216.2019.1583048

Tactical Urbanism Now! Terraviva Competitions - Competition Brief (1 September 2020). Citing Internet source https://www.terravivacompetitions.com/tactical-urbanism-nowcompetition/

United Nations ESCAP. (2017). Sustainable Urban Transport Index (SUTI) for Asian Cities: Greater Jakarta Area, Indonesia. (October), 30-31

Utami, W. N., \& Kusuma, H. E. (2016). Identifikasi Faktor Kebutuhan ‘ Area Transisi ' : Persepsi Pejalan Kaki terhadap Jarak Berjalan Kaki di Kawasan Pusat. 37-44.

Valipour, E., Mobaraki, A., Nikoofam, M., \& Tayyebisoudkolaei, S. (2019). Establishment of Space syntax to read and analyze urban network; the case of study, Famagusta city of Cypru. Journal of Contemporary Urban Affairs, 3(1), 154-160. https://doi.org/10.25034/ijcua.2018.4692

Wardhani, Mustika K. (2018). Titik Nol Kilometer Kota Yogyakarta sebagai Ruang Terbuka Publik ditinjau dari Dimensi Fungsional, Sosial, dan Visual. Jurnal Planologi. https://doi.org/10.30659/jpsa.v15i1.2739

Yassin, H. H. (2019). Livable City: An approach to pedestrianization through tactical urbanism. Alexandria Engineering Journal, 58(1), 251-259. https://doi.org/10.1016/j.aej.2019.02.005 